\title{
Infraclavicular Topography of the Brachial Plexus Fascicles in Different Upper Limb Positions
}

\author{
Topografía Infraclavicular de los Fascículos del Plexo Braquial \\ en Diferentes Posiciones del Miembro Superior
}

Daniel Alves dos Santos*; Amilton Iatecola*; Cesar Adriano Dias Vecina*; Eduardo Jose Caldeira**; Ricardo Noboro Isayama**; Erivelto Luis Chacon**; Marianna Carla Alves"*; Evanisi Teresa Palomari"**; Maria Jose Salete Viotto**** \& Marcelo Rodrigues da Cunha*,**

ALVES DOS SANTOS, D.; IATECOLA, A.; DIAS VECINA, C. A.; CALDEIRA, E. J.; NOBORO ISAYAMA, R.; CHACON, E. L.; ALVES, M. C.; PALOMARI, E. T.; SALETE VIOTTO, M. J. \& RODRIGUES DA CUNHA, M. Infraclavicular topography of the brachial plexus fascicles in different upper limb positions. Int. J. Morphol., 34 (3):1063-1068, 2016.

SUMMARY: Brachial plexus neuropathies are common complaints among patients seen at orthopedic clinics. The causes range from traumatic to occupational factors and symptoms include paresthesia, paresis, and functional disability of the upper limb. Treatment can be surgical or conservative, but detailed knowledge of the brachial plexus is required in both cases to avoid iatrogenic injuries and to facilitate anesthetic block, preventing possible vascular punctures. Therefore, the objective of this study was to evaluate the topography of the infraclavicular brachial plexus fascicles in different upper limb positions adopted during some clinical procedures. A formalinpreserved, adult, male cadaver was used. The infraclavicular and axillary regions were dissected and the distance of the brachial plexus fascicles from adjacent bone structures was measured. No anatomical variation in the formation of the brachial plexus was observed. The metric relationships between the brachial plexus and adjacent bone prominences differed depending on the degree of shoulder abduction. Detailed knowledge of the infraclavicular topography of neurovascular structures helps with the diagnosis and especially with the choice of conservative or surgical treatment of brachial plexus neuropathies.

KEY WORDS: Brachial plexus; Topography; Peripheral nerve injuries; Upper limb.

\section{INTRODUCTION}

Brachial plexus injuries are common conditions encountered in outpatient clinics and referral centers for peripheral nerve injuries. These injuries cause motor and sensory loss in the upper limb and consequent socioeconomic and psychological problems (Flores, 2006; Mello Junior et al., 2011). The causes of brachial plexus injuries are diverse and a large number are related to traction of the brachial plexus accompanied by root avulsion due to sudden movements of the shoulder girdle and neck, which occur in motorcycle accidents. Most brachial plexus injuries affect young males around the age of 30 years (Flores, 2006). Other causes of brachial plexus neuropathies include compression and pinching of the nerves due to anatomical variations and clinical complications caused by clavicle fracture, thoracic outlet syndrome, scalenus syndrome, pectoralis minor syndrome, and presence of a cervical rib (Ghefter et al., 2012).
Flores (2006) evaluated patients with traumatic peripheral nerve injuries and concluded that most were brachial plexus injuries. There was a predominance of supraclavicular injuries due to excessive traction, while a small proportion were infraclavicular injuries related to accidents caused by firearm projectiles. Other causes such as compression and sharps injuries were also observed. In this respect, the mechanisms underlying damage to the brachial plexus and its infraclavicular terminal branches are related to partial or total lacerations caused by stretching or penetrating trauma.

In neurocompression syndromes in which the nerves have difficulties in accommodating themselves inside the neural canal during wide upper limb motion, the neural blood supply and axoplasmic flow are reduced, resulting in the formation of connective tissue in structures adjacent to the

\footnotetext{
Laboratory of Anatomy, Centro Universitário Nossa Senhora do Patrocínio (CEUNSP), Itu, São Paulo, Brazil

** Department of Morphology and Pathology, Faculdade de Medicina de Jundiaí (FMJ), Jundiaí, São Paulo, Brazil

*** Department of Anatomy, Universidade Estadual de Campinas (UNICAMP), Campinas, São Paulo, Brazil

***** Department of Anatomy, Universidade Federal de São Carlos (UFSCar), São Carlos, São Paulo, Brazil
} 
ALVES dos SANTOS, D.; IATECOLA, A.; DIAS VECINA, C. A.; CALDEIRA, E. J.; NOBORO ISAYAMA, R.; CHACON, E. L.; ALVES, M. C.; PALOMARI, E. T.; SALETE VIOTTO, M. J. \& RODRIGUES DA CUNHA, M. Infraclavicular topography of the brachial plexus fascicles in different upper limb positions. Int. J. Morphol., 34 (3):1063-1068, 2016.

nerve and in the nerve tissue itself. These events render the nerve immobile and increase the difficulty of adaptation to the arcs of motion, in addition to impairing neural healing. Symptoms include irradiating pain, deformities, paresthesia, and paresis of the affected upper limb (Butler, 2004).

Knowledge of the infraclavicular topography of the brachial plexus is important for the evaluation of these injuries, as well as parameters during upper limb surgical procedures that require brachial plexus block (Gusmão et al., 2002). According to Imbelloni et al. (2001), infraclavicular block of the brachial plexus provides adequate anesthesia in cases of upper limb surgery and knowledge of the local anatomy is essential to prevent errors such as vascular punctures or complications due to pneumothorax.

Several studies on the prognosis, surgical techniques and treatment of peripheral nerve injuries are available in the literature, but little is known about the morphometry of the brachial plexus fascicles in the infraclavicular region and its application to increase the safety and success of surgical procedures. Therefore, the objective of the present study was to contribute to the understanding of the infraclavicular topography of the brachial plexus fascicles in different upper limb positions. It was not the intention to discuss conservative and surgical treatments.

\section{MATERIAL AND METHOD}

Sample and dissection procedure. A formalinpreserved adult male cadaver was obtained from the Laboratory of Anatomy, School of Health and Life Sciences, Centro Universitário Nossa Senhora do Patrocínio (CEUNSP), Itu, São Paulo, Brazil. First, the sternal, pectoral, inframammary, lateral pectoral, infraclavicular and axillary regions were demarcated. Next, a skin incision was made with a scalpel following the lower margin of the right clavicle, parasternal line, inframammary line, and posterior axillary line. The skin was separated and the subcutaneous tissue was removed, exposing the pectoralis major and serratus anterior muscles. The pectoral fascia was dissected and the pectoralis major was cut at its humeral insertion, permitting identification of the clavipectoral fascia immediately above the pectoralis minor muscle. Sectioning exposed the infraclavicular neurovascular structures, including the transition between the subclavian and axillary vessels and the brachial plexus fascicles, as well as the distribution of its terminal branches in the axillary fossa and medial bicipital groove of the arm (Fig. 1).

Morphometric analysis. A digital caliper (Standard Gage) was used to measure the distance of the fascicles (medial,

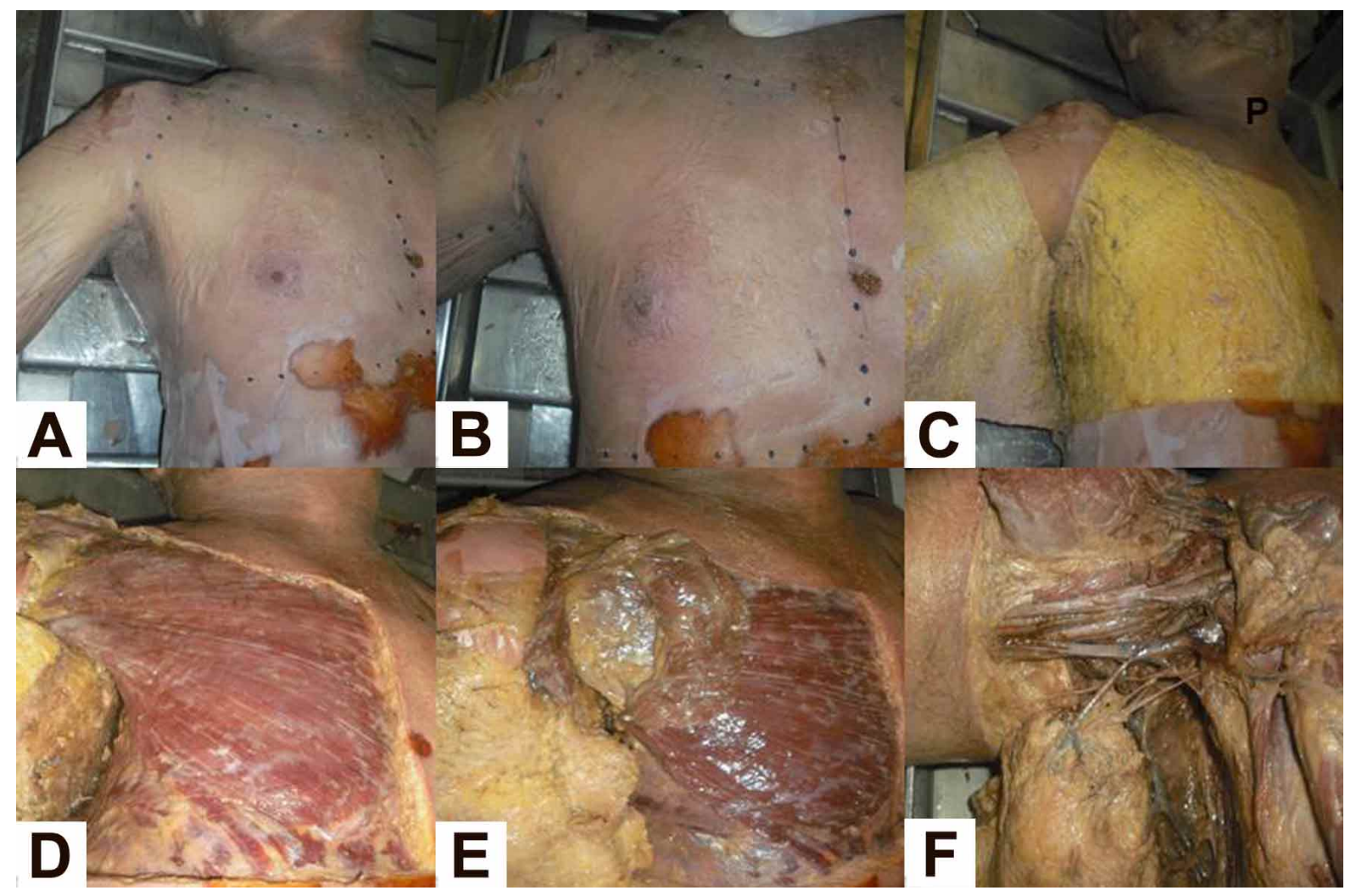

Fig. 1. Sequence of stratigraphic dissection of the infraclavicular region of the cadaver. 
Table I Metric relationships ( $\mathrm{T}$ ) between the brachial plexus and adjacent structures.

\begin{tabular}{lll}
\hline \multicolumn{1}{c}{ Metric } & \multicolumn{1}{c}{ References 1 } & \multicolumn{1}{c}{ References 2 } \\
relantionship (T) & & \\
\hline T1 & Lateral fascicle & Coracoid process \\
T2 & Lateral fascicle & Crest of lesser tubercle \\
T3 & Lateral fascicle & Body of clavicle \\
T4 & Lateral fascicle & Midaxillary line \\
T5 & Medial fascicle & Coracoid process \\
T6 & Medial fascicle & Crest of lesser tubercle \\
T7 & Medial fascicle & Body of clavicle \\
T8 & Medial fascicle & Midaxillary line \\
T9 & Posterior fascicle & Coracoid process \\
T10 & Posterior fascicle & Crest of lesser tubercle \\
T11 & Posterior fascicle & Body of clavicle \\
T12 & Posterior fascicle & Midaxillary line \\
\hline
\end{tabular}

lateral, and posterior) of the brachial plexus from the following anatomical landmarks: coracoid process of the scapula, crest of the lesser tubercle of the humerus, middle third of the clavicle, and mid-axillary line at the height of the third rib bow. Each measurement was obtained with the upper limb of the cadaver at $30^{\circ}, 60^{\circ}$ and $90^{\circ}$ shoulder abduction standardized with a goniometer (CARCI), considering cadaveric rigidity (Table I).

\section{RESULTS}

Infraclavicular topography of the brachial plexus. Dissection of the cadaver revealed no anatomical variation in the infraclavicular formation of the brachial plexus fascicles by the nerve trunks originating from roots $\mathrm{C} 5$ to $\mathrm{T} 1$. Furthermore, there was no alteration in the relationship of the fascicles with adjacent vascular structures, or in their deep location to the clavipectoral fascia and pectoralis minor. The fascicles lying deep to the clavipectoral triangle emitted their terminal branches from the beginning of the upper margin of the axillary fossa. The lateral fascicle had an anterior projection compared to the medial and posterior fascicles. No alteration was observed in the origin or relationships of the peripheral nerves arising from the fascicles. In the different positions of upper limb abduction, with stabilization of the shoulder and considering cadaveric rigidity, the angle of $90^{\circ}$ caused displacement and overstretching of the fascicles in the axillary region and discrete traction of the nerve trunks and roots in the supraclavicular area of the brachial plexus (Fig. 2). Rotation of the cadaver's head to the site opposite of the brachial plexus showed greater stretching in the supraclavicular area and no marked impairment of the topography or infraclavicular tension of the fascicles.

Morphometric analysis. A marked reduction in T1, T5 and T9 was observed at the largest abduction angle analyzed, reflecting approximation of the brachial plexus fascicles in the direction of the coracoid process and tendon of insertion proximal to the pectoralis minor muscle. A slight increase was observed in the other measures when the abduction angle was increased from $30^{\circ}$ to $60^{\circ}$. An increase of the angle from $60^{\circ}$ to $90^{\circ}$ resulted in a decrease of T1, T2, T3, T5, T7, T9, T10, and T11 (Table 2 and Fig. 3).

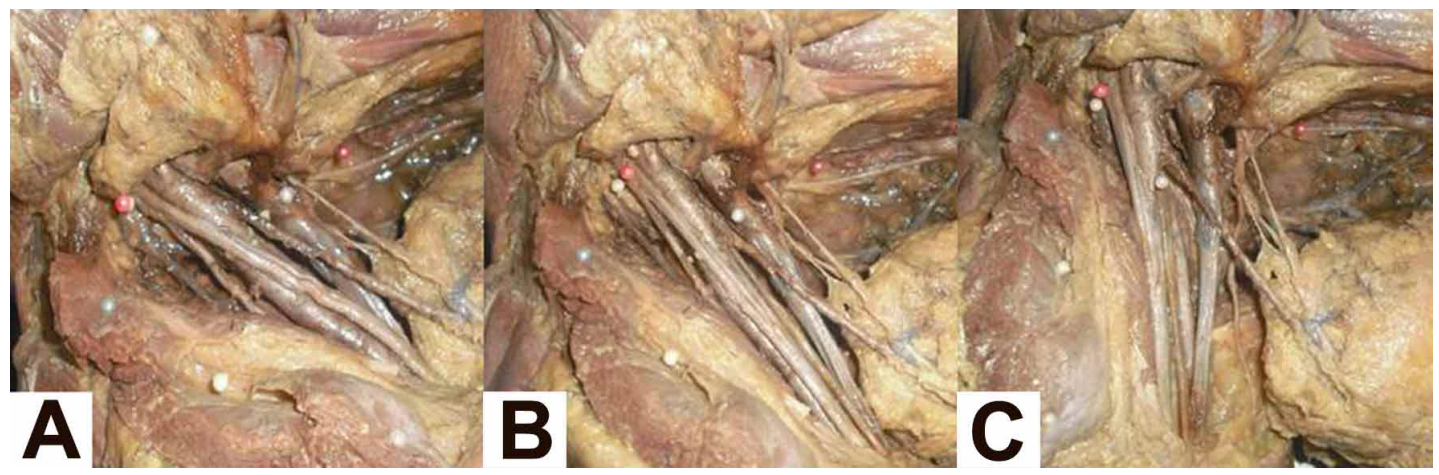

Fig. 2 Infraclavicular region of the cadaver in shoulder abduction at $30^{\circ}(\mathrm{A}), 60^{\circ}(\mathrm{B})$ and $90^{\circ}(\mathrm{C})$. Note the stretching of the brachial plexus fascicles concomitant to the increase in the range of motion in the frontal plane. Magnification: $5 x$.

Table II Metric relationship ( $\mathrm{mm}$ ) between the landmarks given in Table I at $30^{\circ}, 60^{\circ}$ and $90^{\circ}$ of shoulder abduction.

\begin{tabular}{|c|c|c|c|c|c|c|c|c|c|c|c|c|}
\hline & T1 & T2 & T3 & T4 & T5 & T6 & T7 & T8 & T9 & T10 & T11 & T12 \\
\hline $30^{\circ}$ & 48.0 & 56.8 & 46.9 & 59.2 & 43.0 & 76.6 & 35.8 & 35.8 & 24.4 & 56.6 & 46.4 & 58.1 \\
\hline $60^{\circ}$ & 38.6 & 58.8 & 47.4 & 59.3 & 35.6 & 78.3 & 41.3 & 41.3 & 21.1 & 58.3 & 49.8 & 60.4 \\
\hline $90^{\circ}$ & 23.2 & 58.0 & 45.4 & 63.6 & 29.7 & 68.0 & 48.7 & 48.7 & 14.0 & 55.1 & 46.5 & 63.3 \\
\hline
\end{tabular}




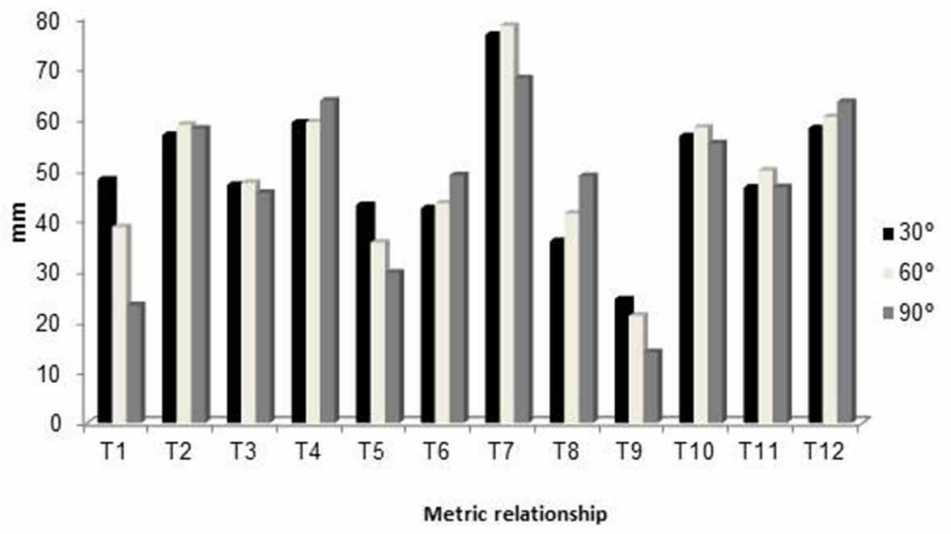

Fig. 3. Metric relationship $(\mathrm{mm})$ between the brachial plexus and adjacent anatomical structures at $30^{\circ}, 60^{\circ}$ and $90^{\circ}$ of shoulder abduction.

\section{DISCUSSION}

Studies have reported different iatrogenic brachial plexus injuries in surgical procedures such as shoulder arthroscopy, cardiac procedures through a median sternotomy, breast tumor resection, and axillary lymph node dissection (Atra \& Gabbai, 1999; Junior et al., 2011; Valinote et al., 2013). Therefore, detailed knowledge of the topography of the brachial plexus in the infraclavicular fossa is necessary, especially in cases requiring anesthetic block (Gusmão et al.).

No anatomical variation in the formation of the brachial plexus or in the location and infraclavicular division of its fascicles and peripheral nerves was observed during dissection of the cadaver used in this study, corroborating the findings of Costabeber et al. (2010). However, Goel et al. (2014) observed a variation during dissection, which consisted of a second nerve root of the lateral fascicle for the origin of the ulnar nerve. Furthermore, the authors found that the musculocutaneous nerve did not pierce the coracobrachial nerve, different from the classical anatomical report of Moore et al. (2013). Other studies also reported differences in topography and brachial plexus formation between gender, ethnicity, and body sites (Fazan et al., 2003). These variables could not be determined and discussed in the present study because only one formalinpreserved male cadaver was used. Similarly, Costabeber et al. also performed a morphological study of the brachial plexus fascicles in only one cadaver and did not observe anatomical variations different from those described in the literature. These data highlight the importance of detailed knowledge of the infraclavicular fossa, taking into consideration possible differences in the arrangement of neurovascular structures between cadavers that differ in gender, race, age, evolution, biotype and other factors that can influence brachial plexus anatomy.
Morphometric analysis provided some interesting data showing that the position of the upper limb interfered with the infraclavicular topography of the fascicles. However, these findings cannot be generalized since only one cadaver was studied and no additional samples were available for comparative statistical analysis. The results of metric analysis showed that $90^{\circ}$ abduction of the upper limb most approximated the fascicles to the coracoid process, providing the lowest value between these anatomical landmarks, in addition to causing greater tension of the fascicles. According to Delamarche et al. (2006), shoulder abduction from zero to $30^{\circ}$ involves only the glenohumeral joint, without movement of the scapula. At a larger angle, shoulder abduction occurs at a 2:1 ratio between the glenohumeral joint through abduction of the humerus and the scapulothoracic joint by lateral rotation of the scapula. Thus, shoulder abduction at $90^{\circ}$ involves $60^{\circ}$ glenohumeral motion and $30^{\circ}$ scapulothoracic motion. These movements modify the position and relationship of the bones of the shoulder girdle and consequently their relationship with the fascicles of the brachial plexus. Costabeber et al. also observed changes in the position of the brachial plexus fascicles and explained this finding by the fact that vascular and nervous structures are surrounded by adipose tissue, which accompany the hyperabduction movements of the upper limb in relation to the chest.

Gusmão et al. found that traction of the brachial plexus could be avoided by positioning the upper limb pending along the body or in slight abduction and that rotation of the head to the opposite side does not interfere with the position of the fascicles. Furthermore, the authors standardized an infraclavicular access to the brachial plexus by studying the depth and location of the fascicles in cadavers. The respective distances of the anterior surface of the clavicle and deltoclavicular angle from the fascicles were 2.49 and $2.21 \mathrm{~cm}$. Magnetic resonance imaging in patients showed that the fascicles were located at a distance of 2.5 $\mathrm{cm}$ from the center of the axillary artery.

The distance of the brachial plexus fascicles from the deltoclavicular angle was not determined in the present study. However, the standardized measures obtained for the referenced bones, in conjunction with the data of the studies of Gusmão et al. and Flores (2011) contribute to a better identification of the depth and body surface projection of the brachial plexus along the infraclavicular and axillary regions considering the biotypes of the subjects used in the studies. These data permit the precise introduction of the 
ALVES dos SANTOS, D.; IATECOLA, A.; DIAS VECINA, C. A.; CALDEIRA, E. J.; NOBORO ISAYAMA, R.; CHACON, E. L.; ALVES, M. C.; PALOMARI, E. T.; SALETE VIOTTO, M. J. \& RODRIGUES DA CUNHA, M. Infraclavicular topography of the brachial plexus fascicles in different upper limb positions. Int. J. Morphol., 34 (3):1063-1068, 2016.

needle into the fascicles without causing puncture of the axillary artery and chest wall, which is important to accomplish brachial plexus block below the level of the clavicle (Gusmão et al.).

With respect to the metric relationship between the brachial plexus and adjacent bone structures, data are limited especially those associating the findings with different upper limb positions. There are only two studies in the literature measuring individual nerves. Pettian et al. (2012) and Cunha et al. (2014), respectively, investigated the topography of the median and ulnar nerves in cadavers and observed an increase in neural tension during shoulder extension. An interesting finding of the present study was the increase in T4, T6, T8 and T12 values with increasing shoulder abduction. Opposite results were obtained for T1, T5 and T9. This finding is probably due to the fact that shoulder abduction causes lateral rotation of the scapula and separation of nerve structures from the plexus in the direction of the coracoid process and acromion of the scapula, producing greater tension of the fascicles (Costabeber et al.). However, studies involving a larger and more diverse sample of cadavers and considering sex, race, age, biotype and cadaveric rigidity are needed to standardize the variations that can occur in the formation and topographic arrangement of the brachial plexus. These data would have a direct impact on the conservative and surgical approach to the treatment of upper limb neuropathies (Gusmão et al.; Butler; Flores, 2006; Flores, 2011 ).

\section{CONCLUSION}

Different positions of the upper limb in the frontal plane cause alterations in the topography and tension of the brachial plexus fascicles. Furthermore, the neurovascular structures in the infraclavicular region exhibit important metric relationships with adjacent bone structures. Taken together with similar data in the literature, these results will serve as references in surgical procedures.

\section{ACKNOWLEDGMENTS}

This work was supported and funded by CEUNSP/ ITU and NAPED/FMJ.

ALVES DOS SANTOS, D.; IATECOLA, A.; DIAS VECINA, C. A.; CALDEIRA, E. J.; NOBORO ISAYAMA, R.; CHACON, E. L.; ALVES, M. C.; PALOMARI, E. T.; SALETE VIOTTO, M. J. \& RODRIGUES DA CUNHA, M. Topografía infraclavicular de los fascículos del plexo braquial en diferentes posiciones del miembro superior. Int. J. Morphol., 34(3):1063-1068, 2016.

RESUMEN: Las neuropatías del plexo braquial son quejas comunes entre los pacientes atendidos en las clínicas ortopédicas. Las causas van desde traumas a factores ocupacionales y los síntomas incluyen parestesias, paresia e incapacidad funcional del miembro superior. El tratamiento puede ser quirúrgico o conservador, pero se requiere un conocimiento detallado del plexo braquial en ambos casos para evitar lesiones iatrogénicas y para facilitar el bloqueo anestésico, evitando posibles lesiones vasculares. Por lo tanto, el objetivo de este estudio fue evaluar la topografía de los fascículos del plexo braquial infraclavicular en diferentes posiciones de los miembros superiores adoptadas durante algunos procedimientos clínicos. Se llevó a cabo la disección de las regiones infraclavicular y axilar de un cadáver adulto, de sexo masculino, conservado en formaldehído. Se midió la distancia de los fascículos del plexo braquial en relación a las estructuras óseas adyacentes. No se observó variación anatómica en la formación del plexo braquial. Las relaciones métricas entre el plexo braquial y las prominencias óseas adyacentes difieren en función del grado de abducción del hombro. El conocimiento detallado de la topografía infraclavicular de las estructuras neurovasculares ayuda con el diagnóstico y sobre todo con la elección del tratamiento conservador o quirúrgico de las neuropatías del plexo braquial.

PALABRAS CLAVE: Plexo braquial; Topografía; Lesiones de nervios periféricos; Miembro superior.

\section{REFERENCES}

Atra, M. \& Gabbai, A. A. The involvement of the brachial plexus in cardiac surgery with median sternotomy for the revascularization of the myocardium: clinical evaluation. Arq. Neuropsiquiatr., 57(4):976-81, 1999.

Butler, D. S. Mobilisation of the Nervous System. Edinburgh, Churchill Livingstone, 2004.
Costabeber, I.; de Almeida, G. M.; Becker, M.; Silveira, A. F. \& Martini, D. T. Brachial plexus cords: a morphological study. Rev. Bras. Anestesiol., 60(6):614-9, 2010.

Cunha, M. R.; Araujo, J. C. G.; Portes, B.; Iatecola, A.; Chacon, E. L.; Galdeano, E. A.; Isayama, R. N. \& Palomari, E. T. Topography of ulnar nerve in different positions of the 
ALVES dos SANTOS, D.; IATECola, A.; DIAS VECinA, C. A.; CALDEIRA, E. J.; NOBORO ISAYAMA, R.; CHACON, E. L.; ALVES, M. C.; PALOMARI, E. T.; SALETE VIOTTO, M. J. \& RODRIGUES DA CUNHA, M. Infraclavicular topography of the brachial plexus fascicles in different upper limb positions. Int. J. Morphol., 34 (3):1063-1068, 2016.

upper limb used in the clinical evaluation. Perspect. Med., 25(3):5-12, 2014.

Delamarche, P.; Dufour, M.; Multon, F.; Perlemuter, L. \& Bilweis, C. Anatomy, Physiology and Biomechanics. Rio de Janeiro, Guanabara Koogan, 2006.

Fazan, V. P. S.; Amadeu, A. S.; Caleffi, A. L. \& Rodrigues Filho, A. O. Brachial plexus variations in its formation and main branches. Acta Cir. Bras., 18 Suppl., 5:14-8, 2003.

Flores, L. P. Epidemiological study of the traumatic brachial plexus injuries in adults. Arq. Neuropsiquiatr., 64(1):88-94, 2006.

Flores, L. P. The importance of the preoperative clinical parameters and the intraoperative electrophysiological monitoring in brachial plexus surgery. Arq. Neuropsiquiatr., 69(4):654-9, 2011.

Ghefter, M. C.; Yoshida, W. B.; Cataneo, D. C.; Hasimoto, E. N.; Yoshida, R. A.; Boscardim, P. C. B. \& Cataneo, A. J. M. Síndrome do desfiladeiro torácico - ressecção de costela cervical por videotoracoscopia. J. Vasc. Bras., 11(3):219-25, 2012.

Goel, S.; Rustagi, S. M.; Kumar, A.; Mehta, V. \& Suri, R. K. Multiple unilateral variations in medial and lateral cords of brachial plexus and their branches. Anat. Cell Biol., 47(1):7780, 2014.

Gusmão, L. C. B.; Lima, J. S. B. \& Prates, J. C. Bases anatômicas para o bloqueio anestésico do plexo braquial por via infraclavicular. Rev. Bras Anestesiol., 52(3):348-53, 2002.

Imbelloni, L. E.; Beato, L. \& Gouveia, M. A. Bloqueio do plexo braquial por via infraclavicular: abordagem ântero-posterior. Rev. Bras. Anestesiol., 51(3):235-43, 2001.

Mello Junior, J. S.; Souza, T. C. R.; Andrade, F. G.; Castaneda, L.; Baptista, A. F.; Nunes S., K.; Vargas, C. D.; Gomes, M. M.; Guedes, J. F, \& Martins, J. V. Perfil epidemiológico de pacientes com lesão traumática do plexo braquial avaliados em um Hospital Universitário no Rio de Janeiro, Brasil, 2011. Rev. Bras. Neurol., 48(3):5-8, 2011.

Moore, K. L.; Dalley, A. F. \& Agur, A. M. R. Clinically Oriented Anatomy. Philadelphia, Wolters Kluwer Health/Lippincott Williams \& Wilkins, 2013.

Pettian, M. S.; Iatecola, A.; Vecina, C. A. D.; Viotto, M. J. S.; Isayama, R. N.; Palomari, E. T. \& Cunha, M. R. Median nerve behavior in different upper limb positions. Int. J. Morphol., 30(4):1280-4, 2012.

Junior, A. C.; Ribeiro, F. R.; Filho, R. B.; Filho, C. S.; Lutfi, H. V. \& Magri, E. A. Comparative anatomical study between the right and left sides of the axillary nerve in relation to deltopectoral approach and acromion. Rev. Bras. Ortop., 46(3):309-14, 2011.
Valinote, S. P.; de Freitas-Junior, R.; Martins, K. A.; Pereira, A. C.; Pereira, C. E. \& Martins, E. Venous and lymphatic alterations in women with lymphedema after axillary lymphadenectomy in breast cancer treatment. Rev. Bras. Ginecol. Obstet., 35(4):171-7, 2013.

Correspondence to:

Prof. Dr. Marcelo Rodrigues da Cunha

Department of Morphology and Pathology

Faculdade de Medicina de Jundiaí

Rua Francisco Telles 250

Vila Arens Jundiaí

CEP. 13202-550

Cx. Postal 1295

São Paulo

BRAZIL

Email: cunhamr@hotmail.com

Received : 03-01-2016

Accepted : 07-07-2016 